\title{
Cracked Pattern of Bamboo Reinforced Concrete Beams Using Double Reinforcement with the Strengthening on Tensile Reinforcement
}

\author{
Muhtar \\ Department of Civil Engineering, Faculty of Engineering, \\ University of Muhammadiyah Jember, Jember, 68121, Indonesia.
}

ORCID: 0000-0002-5734-2728

\begin{abstract}
:
The cracks in BRC beams are usually less and do not spread when compared to SRC beam cracks. The initial crack of the BRC beam is always followed by the propagation of the crack in the same location and no cracking occurs at the new location. The majority of cracks are horizontal and only slightly vertical. This study aims to increase bond strength and evaluate crack patterns of BRC beams of double reinforcement by strengthening bamboo reinforcement using hose clamps and adhesives. Beam test specimens were made in 4 pieces with different treatments. The dimensions of the bamboo reinforcement are $1.5 \mathrm{~cm} \times 1.5 \mathrm{~cm}$. The dimensions of the concrete beam are $12 \mathrm{~cm}$ x $20 \mathrm{~cm}$ x $210 \mathrm{~cm}$. The tensile reinforcement ratio is used at $4.67 \%$ and the compression reinforcement ratio is $1.88 \%$. The beam test is carried out using a four-point load. The test results showed an increase in the bond-strength at the BRC beam with strengthening the tensile reinforcement and the crack is more diffuse when compared with the BRC beam no strengthening.
\end{abstract}

Keywords: Keywords: Cracked Pattern, Bamboo Reinforced Concrete (BRC), Bond-Strength, Double Reinforcement.

\section{INTRODUCTION}

Bamboo grows most in areas of the country that have a tropical climate. Indonesia is a country with a tropical climate with abundant bamboo plants. Bamboo is widely used as household appliances but is also widely used as a construction material as non-permanent warehouses, simple rural houses, bridges and so on. Some reasons bamboo is widely used because it has high tensile strength and low prices. However, bamboo has the disadvantage that bamboo resistance is very low if not treated first.

Bamboo as concrete reinforcement must be soaked, dried and covered with a waterproof coating. This is intended to prevent the action of absorbing each other between bamboo and concrete. Water absorption occurs in two stages. The first phase of wet concrete will be absorbed by bamboo and after the concrete has hardened, the water in the bamboo will be absorbed by the concrete. This process is called the hygroscopic and hydrolysis process which lasts for an infinite amount of time. If bamboo is not coated with a waterproof layer, it will absorb each other and the bamboo will shrink as shown in Figure 1 [1]. Various types of waterproof coatings that are widely used include Sikadur ${ }^{\circledR}-752$ [2], [3], [4], [5], [6], Sikadur 32 Gel [7], [8], Sika Hibond [9], etc.
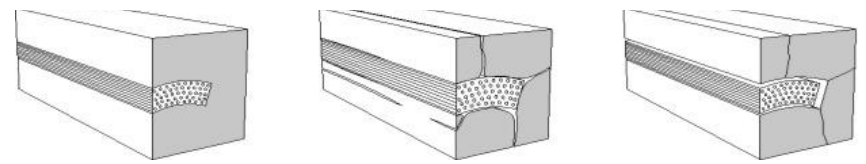

Fig. 1. Swelling of bamboo reinforcement in concrete and occurrence micro-cracking [1]

Bamboo has a variety of types. In Indonesia, bamboo species that have high tensile strength are Petung bamboo (Dendrocalamus asper) and Ori bamboo. Petung bamboo is a bamboo that has a large stem circumference, covered with brown feathers to black, segment long among $40-50 \mathrm{~cm}$ and $12-18 \mathrm{~cm}$ in diameter, overall reed reaches up to $20 \mathrm{~m}$ high with a curved tip. Petung bamboo wall thickness between 11 to $36 \mathrm{~mm} \mathrm{[10]} \mathrm{in} \mathrm{Wikipedia} \mathrm{Indonesia} \mathrm{(2016).}$

Bamboo as a reinforcement of concrete beams still shows slip failure due to the low bond-stress between bamboo reinforcement and concrete. The use of bamboo reinforcement in reinforced concrete beams requires treatment. Eliminating starch content, drying, applying the waterproof coating, and sand treatment is a must. However, the collapse of the bamboo reinforced concrete beam element still occurred due to the slip on the bamboo reinforcement. To increase the shear capacity of the bamboo reinforcement, strengthening is needed to modify the surface roughness of the bamboo reinforcement, one of which is giving a hose-clamp as a shear connector and an adhesive as a waterproof layer.

Modification of bamboo reinforcement roughness has been done a lot, including notches [11], wire and coir windings [12], and the addition of hooks. This method can increase the carrying capacity of the beam, but there are still many weaknesses, such as the implementation is relatively difficult and the notch process can weaken bamboo reinforcement. To increase the stickiness of bamboo reinforcement with concrete, a hose-clamp is installed on the bamboo reinforcement which also functions as a shear connector.

The use of hose-clamps on bamboo reinforcement is based on the concept of using deform bars on concrete, where when the pulling force occurs there will be an interaction between 
friction and fulcrum between concrete and bamboo reinforcement [5].

The bamboo reinforcement must also function as a waterproof layer and sand sprinkle adhesive on the bamboo reinforcement. Some types of adhesives that have been widely used by researchers include Water-based epoxy coating with coarse sand, Water-based epoxy coating with fine sand, TrueGrip EP with coarse sand, BP TrueGrip with coarse sand, Exaphen with coarse sand, and Enamel [1]; Araldite, Epoxy Resin, and Coal Tar [13]; dry paint and sand [14]; epoxy and fine sand [15]; Negrolin, Sikadur 32 Gel [7]; Araldite, Tepecrete P-151, Anti Corr RC, and Sikadur 32 Gel [8]; and asphalt and sand bamboo reinforcement [16]. From some of the studies mentioned above Sikadur $32 \mathrm{Gel}$ adhesive is the adhesive with the best test results. However, PT. Sika Indonesia does not produce Sikadur $32 \mathrm{Gel}$. The produce of PT. Sika Indonesia is currently Sikadur ${ }^{\circledR}-752$ [4].

\section{MATERIAL AND METHODS}

\section{A. Bamboo, Hose clamp, and Adhesive}

The bamboo used is bamboo "petung" (Dendrocalamus asper) aged 3-5 years with a length of 3-6 meters from the bottom of the bamboo trunk. Bamboo is cut and shaped reinforcement according to the planned size. Then the treatment process is carried out [4]. The waterproof coating used is the adhesive "Sikadur ${ }^{\circledR}-752 "$ [4]. Sikadur ${ }^{\circledR}-752$ is a solvent-free liquid, super low viscosity, and high-strength epoxy resin. Usually used to seal concrete cavities and cracks, increase bond strength and improve structural integrity. The hose-clamps used are made in Taiwan with a diameter of $3 / 4$ ". Treatment of bamboo reinforcement with Sikadur ${ }^{\circledR}-752$ and sand are shown in Figure 2. The application of bamboo reinforcement which has been treated with Sikadur ${ }^{\circledR}-752$ and sand on the BRC beam is shown in Figure 3.

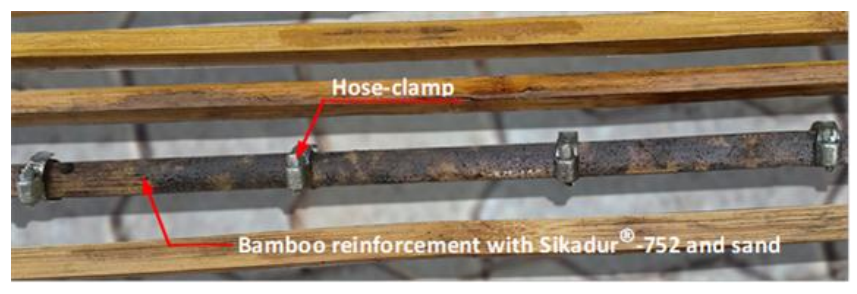

Fig. 2. Treatment of bamboo reinforcement with Sikadur ${ }^{\circledR}$ 752 and sand

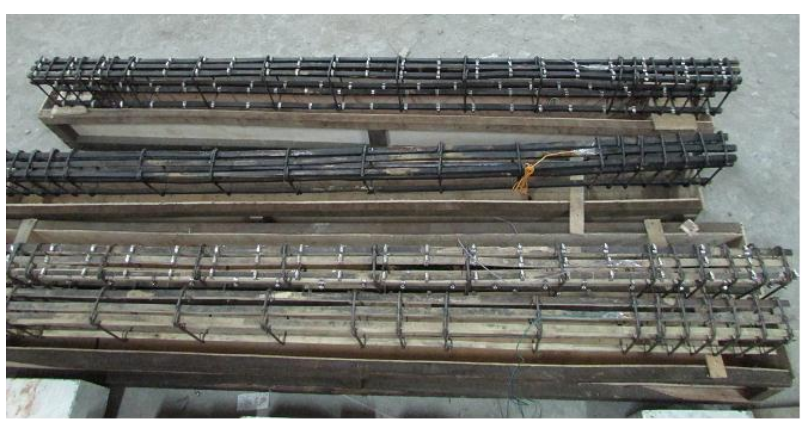

Fig. 3. The specimens of beam BRC of double reinforcement with hose-clamp and adhesive

\section{B. $\quad$ Testing Methods}

The dimensions of the bamboo reinforcement are $1.5 \mathrm{~cm} \times 1.5$ $\mathrm{cm} x$ the length of the bamboo. The dimensions of the double reinforcement concrete beam are $12 \mathrm{~cm} \times 20 \mathrm{~cm} \times 210 \mathrm{~cm}$, with a tensile reinforcement ratio $(\rho)$ of around $4.68 \%$ and a compression reinforcement ratio $\left(\rho^{\prime}\right)$ of around $1.88 \%$. Shear reinforcement used steel reinforcement with a diameter of 6 $\mathrm{mm}$. Four test beams were made with different tensile reinforcement treatments, namely: (B1) normal reinforcement, (B2) with hose-clamps, (B3) with waterproof layers, and (B4) with waterproof layers and hose-clamps as shown in Figure 4. Figure 4 shows the dimensions and details of beam reinforcement. The beam test is carried out using a four-point load. Beams are tested for bending after 28 days of treatment. The specimens were tested on a loading frame capacity of 150 $\mathrm{kN}$ and a load cell with a capacity of $100 \mathrm{kN}$. The test and loading scheme is shown in Figure 5.

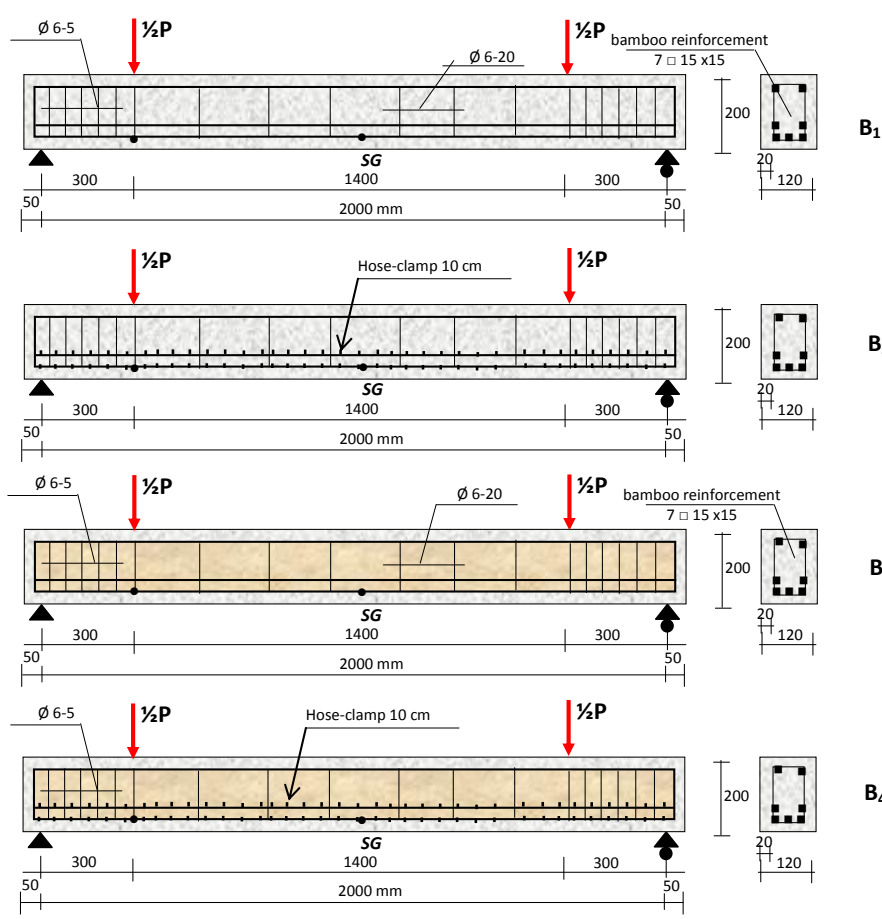

Fig. 4. The reinforcement details and size of bamboo reinforced concrete beams

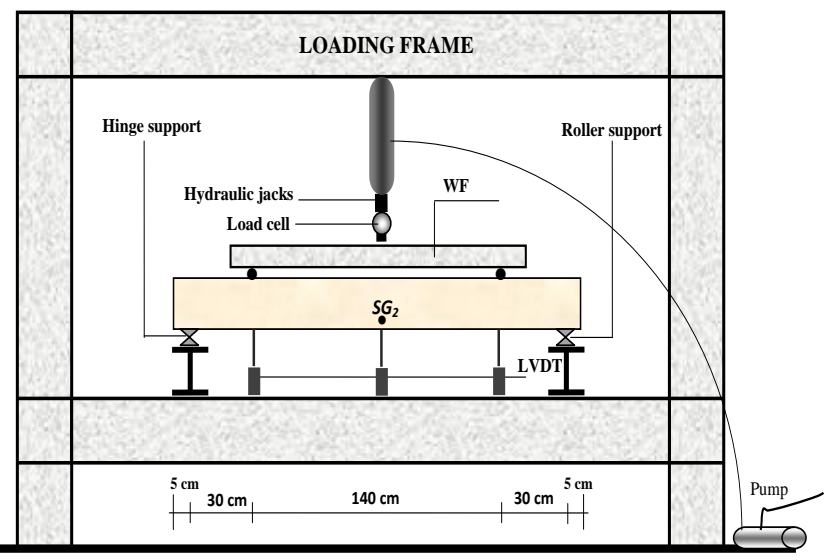

Fig. 5. The setting of BRC beam flexural test using the fourpoint method 


\section{RESULTS AND DISCUSSION}

\section{A. Beam flexural test}

The analysis of flexural bamboo reinforced concrete beams using double reinforcement in this study refers to the Ghavami study [7,2]. The balance between the compressive forces on the concrete $\left(C=C b^{\prime}+C c\right)$ and the tensile forces $(T)$ must be met as shown in Figure 6. Tensile force to bamboo reinforcement $(T)$ is obtained by multiplying the stresses by juxtaposition (Tensile test results) with the shear reinforcement area because based on previous research the collapse of bamboo reinforced concrete beams caused by the loss of bond between bamboo and concrete.

Bond-strength of bamboo reinforcement with concrete can be seen of bond-stress that occurs between bamboo reinforcement with concrete. The bond-stress $(u)$ calculation on the BRC beam from the flexural test results is based on Equation (1) and Equation (2) [5], the calculation results are shown in Table 1. Data from the results of the calculation of the bond-stress of the experimental results of the BRC beam are shown in Table 1.

$$
\begin{aligned}
& u=\frac{V}{j d \cdot \Sigma_{o}} \\
& j d=(d-1 / 2 a)
\end{aligned}
$$

where $\sum o$ is the circumference of the nominal surface area of the bamboo reinforcement in length units, $V$ is the shearing force of the beam, $d$ is the distance from the center of maximum press field to the center of bamboo tensile reinforcement area, and $a$ is the height of concrete stress block equivalent.

Figure 7 shows that slip starts to occur when the load is around $20 \%$ of the ultimate load. As load and bond-stress increase, slips continue to increase. The bond-stress $(u)$ vs slip $(s)$ curve tends to be linear and flat until the maximum bonding stress occurs.

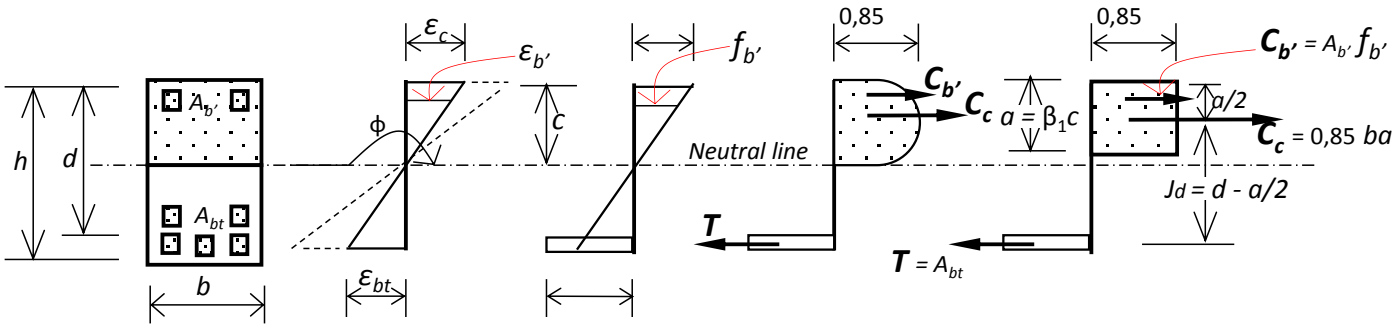

Fig. 6. Diagram of stress-strain distribution in a cross-section of the BRC beam of double reinforcement

Table I: Comparison of flexural test results and theoretical calculations

\begin{tabular}{|l|c|c|c|c|c|c|}
\hline \multirow{2}{*}{ Specimens } & \multicolumn{2}{|c|}{ Theoretical calculations } & \multicolumn{3}{|c|}{ Flexural test results } & $\begin{array}{c}\text { Bond stress flexural } \\
\text { beam }(\boldsymbol{\mu})(\mathbf{M P a})\end{array}$ \\
\cline { 2 - 7 } & $\begin{array}{c}\text { First crack } \\
\text { load }(\mathbf{k N})\end{array}$ & $\begin{array}{c}\text { Ultimete } \\
\text { load }(\mathbf{k N})\end{array}$ & $\begin{array}{c}\text { First crack } \\
\text { load }(\mathbf{k N})\end{array}$ & $\begin{array}{c}\text { Failure } \\
\text { load }(\mathbf{k N})\end{array}$ & $\begin{array}{c}\text { Deflection at } \\
\text { failure }(\mathbf{m m})\end{array}$ & \\
\hline B1-Normal & 21.6 & 78.3 & 16.0 & 60.0 & 28.5 & \\
\hline B2-Hose clamp 10 cm & 21.6 & 82.5 & 16.5 & 52.5 & 29.6 & 0.75 \\
\hline B3-Sikadur ${ }^{\circledR}-752$ & 21.6 & 183.6 & 20.0 & 98.3 & 33.3 & 0.66 \\
\hline $\begin{array}{l}\text { B4- Sikadur } \\
\text { clamp } 10 \mathrm{~cm}\end{array}$ & 21.6 & 198.5 & 19.5 & 80.5 & 28.2 & 1.62 \\
\hline
\end{tabular}

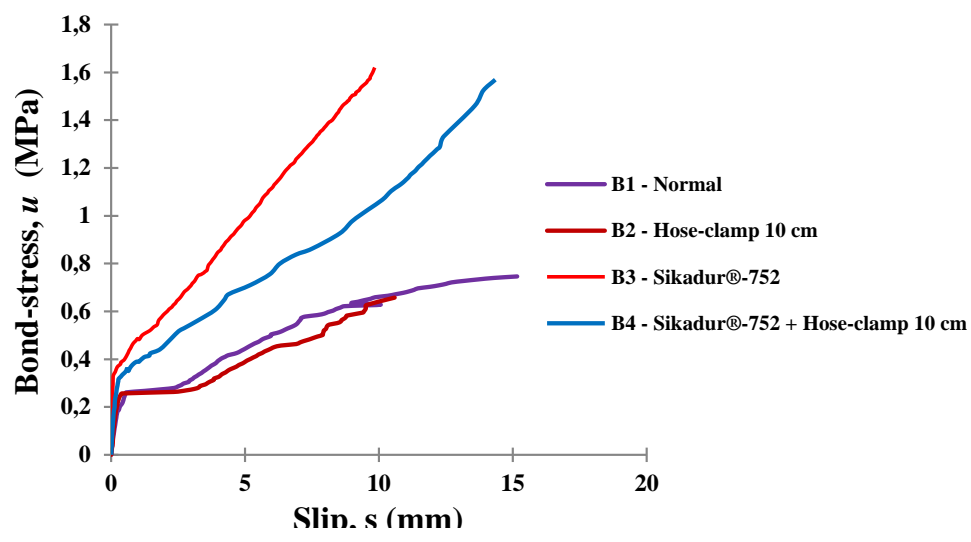

Fig. 7. The relationship graph of bond-stress vs slip of BRC beam 


\section{B. The crack patterns and the relationship of load vs deflection}

Figure 8 and Figure 9 show the relationship of load $(P)$ vs deflection $(\Delta)$ and crack patterns of bamboo reinforced concrete beams. Figure 9 shows the crack pattern of a bamboo reinforced concrete beam with Sikadur ${ }^{\circledR}-752$ adhesive and hose-clamp having more cracks and more spread. This shows that strengthening on bamboo reinforcement using hose-clamp and Sikadur ${ }^{\circledR}-752$ adhesive can increase the load capacity and increase cracking which is more spread as shown in Figure 9 and the video on the following link: http://bit.ly/2IYw5VG. However, the installation of a hose-clamp that is too tight can cause the elasticity of bamboo is reduced. The installation of hose clamps that are too tight causes the BRC beam to become less ductile. Therefore, further research is needed for effective hose-clamp mounting distances.

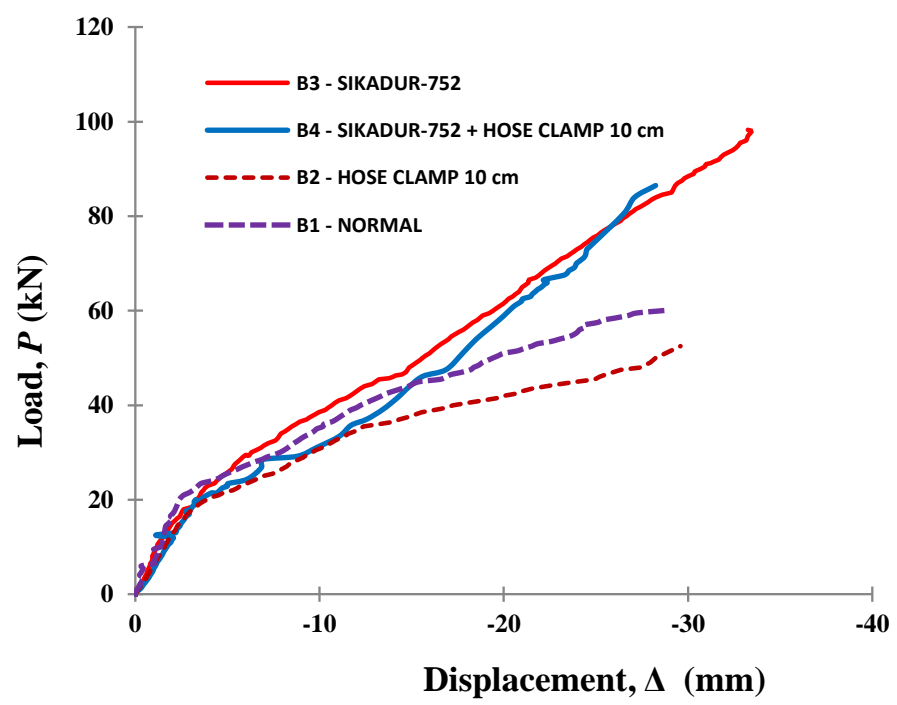

Fig. 8. The relationship graph of load vs displacement of BRC beam

The deflection of the beam is recorded for every $0.5 \mathrm{kN}$ load increase until the beam has collapsed or up to the ultimate load. Data from the results of the calculation of the maximum load of experimental results and the results of theoretical calculations of the BRC beam are shown in Table 1. Figure 8 is the relation of load vs displacement from the results of the BRC beam bending test with the following explanation:

\section{B1 Normal Beam}

The load and deflection relationship at the beginning of loading is still a straight line showing full elastic behavior until the load is $16 \mathrm{kN}$ or at the beginning of the crack occurs. The curve after the initial crack occurs tends to be linear until the beam collapses. The linear load-deflection curve stops at a collapse load of $60 \mathrm{kN}$ with a maximum deflection of 28.57 $\mathrm{mm}$.

\section{B2 Beam withe hose-clamps $10 \mathrm{~cm}$}

The load and deflection relationship of the B2 beam is almost the same as the B1 beam, but there is an initial crack load increase of $0.5 \mathrm{kN}$ to $16.5 \mathrm{kN}$. The curve after the initial crack is slower than curve B1 but still behaves linearly. Likewise, the collapse load is lower than the B1 collapse load, which is $52.5 \mathrm{kN}$ with a maximum deflection of $29.60 \mathrm{~mm}$.

\section{3. $\quad$ B3 Beams with Sikadur ${ }^{\circledR}-752$}

The load and deflection relationship from initial loading to initial crack is a straight line, which shows full elastic behavior until a load of $20 \mathrm{kN}$ or at the initial crack occurs. As the load increases, the curve is slightly more gentle and tends to be linear until the beam collapses. The collapse load occurs at a load of $98.30 \mathrm{kN}$ with a maximum deflection of 33.26 $\mathrm{mm}$. The increase in initial crack load and collapse load of B1 and B2 beams is due to the influence of the Sikadur ${ }^{\circledR}-752$ adhesive and the sand coating on the bamboo reinforcement. Bamboo reinforcement with adhesive Sikadur ${ }^{\circledR}-752$ increases the capacity and ductility of bamboo reinforced concrete beams. This can be seen from the more diffuse crack pattern, the deflection increases with the increasing load without collapse, and the collapse load is greater than other beams, and returns flat after the load release without significant damage. The crack pattern of the four beams is shown in Figure 9.

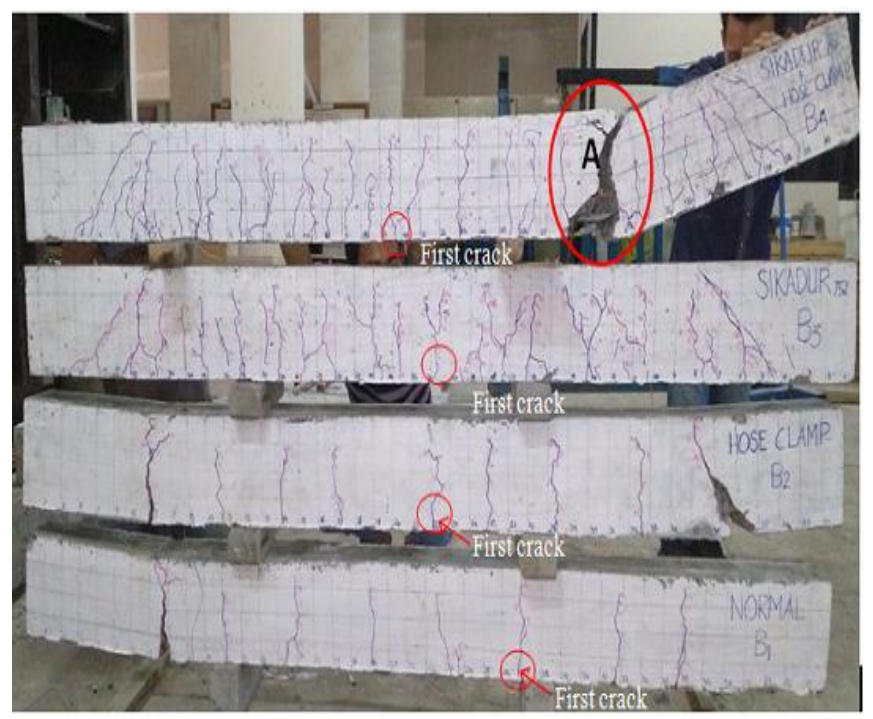

Fig. 9. Crack patterns and fracture behavior of bamboo reinforced concrete beams specimens

4. B4 Beams using Sikadur ${ }^{\circledR}-752+$ hose-clamp $10 \mathrm{~cm}$

The load and deflection relationship at the beginning of loading is still in the form of a straight line showing full elastic behavior until the load is $19.50 \mathrm{kN}$. As load increases, curves are more gentle and tend to be linear. But at this step, fluctuating deflection up and down and the sound on the test beam. This shows the sound of shear transfer from bamboo reinforcement to concrete through hose-clamps. B4 beam collapse occurs at a load of $80.50 \mathrm{kN}$ with a maximum deflection of $28.24 \mathrm{~mm}$. The B4 beam has a capacity similar to the B3 beam. However, the B4 beam has smaller ductility, this is caused by the reduced flexural properties of bamboo reinforcement due to the installation of hose-clamps too tightly. 
International Journal of Engineering Research and Technology. ISSN 0974-3154 Vol.13, No.3 (2020), pp. 608-612

(C) International Research Publication House. https://dx.doi.org/10.37624/IJERT/13.3.2020.608-612

\section{CONCLUSION}

- Based on the results of experiments on BRC beams using double reinforcement show crack patterns and collapsing due to failure of slippage, but BRC beams with bamboo reinforcement coated by waterproof material and hose-clamps have more cracks and spread before collapsing.

- Strengthening the tensile reinforcement by modifying the roughness of the bamboo reinforcement using a hose-clamp and give a waterproof coating can increase the bond-strength and the BRC beam capacity.

- Installation of hose-clamps can increase the stiffness and bond-stress, but the installation of a hose-clamp that is too tight can reduce the ductility of bamboo reinforced concrete beams.

- Installation of hose-clamp on bamboo reinforcement without adhesive or waterproof coating does not affect the BRC beam capacity.

\section{ACKNOWLEDGMENT}

Funding for this research was fully funded by the Directorate of Research and Community Service, the Directorate General of Research and Technology Strengthening and Development of the Ministry of Research, Technology and Higher Education of the Republic of Indonesia or DRPM of the Republic of Indonesia.

\section{REFERENCES}

[1] A. Javadian, M. Wielopolski, I.F.C. Smith, D.E. Hebel, Bond-behavior study of newly developed bamboocomposite reinforcement in concrete, Construction and Building Materials. 122 (2016) 110-117.

[2] Muhtar, S.M. Dewi, A. Munawir, The flexural behavior model of bamboo reinforced concrete beams using a hose clamp, Proceedings in Materials Science, Engineering and Chemistry. 1033 (2019).

[3] Muhtar, S.M. Dewi, Wisnumurti, A. Munawir, The Stiffness and Cracked Pattern of Bamboo Reinforced Concrete Beams Using a Hose Clamp, International Journal of Civil Engineering and Technology (IJCIET). 9 (2018) 273-284.

[4] Muhtar, Experimental data from strengthening bamboo reinforcement using adhesives and hose-clamps, Data in Brief. 27 (2019) 104827.

[5] Muhtar, S.M. Dewi, Wisnumurti, A. Munawir, Enhancing bamboo reinforcement using a hose-clamp to increase bond- stress and slip resistance, Journal of Building Engineering. 26 (2019) 100896.

[6] M. Muhtar, Numerical validation data of tensile stress zones and crack zones in bamboo reinforced concrete beams using the Fortran PowerStation 4.0 program, Data in Brief. (2020) 105332.
[7] K. Ghavami, Bamboo as reinforcement in structural concrete elements, Cement and Concrete Composites. 27 (2005) 637-649.

[8] A. Agarwal, B. Nanda, D. Maity, Experimental investigation on chemically treated bamboo reinforced concrete beams and columns, Construction and Building Materials. 71 (2014) 610-617.

[9] R.N. Bhowmik, J. Pal, P.P. Sarkar, An Experimental Study on Behaviour of Bamboo Reinforced Brick Aggregate Concrete Beam, International Journal of Engineering and Technology (IJET). 9 (2017) 11961203.

[10] W. Indonesia, Bambu petung.pdf, (2016). https://id.wikipedia.org/wiki/Bambu_betung.

[11] A.S. Budi, A.P. Rahmadi, E. Rismunarsi, Experimental Study of Flexural Capacity on Bamboo Ori Strip Notched V Reinforced Concrete Beams, in: AIP Conf. Proc. 1788 - International Conference on Engineering, Science and Nanotechnology 2016 (ICESNANO 2016), American Institute of Physics, 2016: pp. 030052-1030052-7.

[12] A. Dey, N. Chetia, Experimental study of Bamboo Reinforced Concrete beams having various frictional properties, Materials Today: Proceedings. 5 (2016) 436-444.

[13] N.B. Siddhpura, D.B. Shah, J. V Kapadia, C.S. Agrawal, J.K. Sevalia, Experimental study on flexural element using bamboo as reinforcement, International Journal of Current Engineering and Technology. 3 (2013) 476-483.

[14] Nindyawati, S.M. Dewi, A. Soehardjono, The Comparison Between Pull-Out Test And Beam Bending Test To The Bond Strength Of Bamboo Reinforcement In Light Weight Concrete, International Journal of Engineering Research and Applications (IJERA). 3 (2013) 1497-1500.

[15] P. V Kumar, V. Vasugi, Study on Mechanical Strength of Bamboo Reinforced, International Journal of Advances in Science Engineering and Technology. 2 (2014) 103-105.

[16] D. Bhonde, P.B. Nagarnaik, D.K. Parbat, U.P. Waghe, Experimental Analysis of Bending Stresses in Bamboo Reinforced Concrete Beam, in: Proceedings of 3rd International Conference on Recent Trends in Engineering \& Technology (ICRTET'2014), Elsevier Ltd., Nagpur, India, 2014: pp. 1-5. 